\title{
Vegetation Community Characteristics Under Different Vegetation Eco-restoration Techniques at Xiangjiaba Hydropower Station
}

\author{
B.Q. Zhao*(**), R.Z. Gao*(**), D. Xia**, L. Xia*(**), W.Q. Zhu*(**) and W.N. Xu *(**)† \\ * Key Laboratory of Disaster Prevention and Mitigation, China Three Gorges University, Yichang, Hubei 443002, China \\ **Engineering Research Center of Eco-environment in Three Gorges Reservoir Region, Ministry of Education, China \\ Three Gorges University, Yichang, Hubei 443002, China \\ †Corresponding author: Wennian Xu; xwn@ctgu.edu.cn
}

Nat. Env. \& Poll. Tech.

Website: www.neptjournal.com

Received: 27-10-2020

Revised: 08-01-2021

Accepted: 22-01-2021

Key Words:

Vegetation eco-restoration

techniques

Vegetation community

Species diversity

Disturbed area

\begin{abstract}
The objective of this study is to understand the characteristics of vegetation communities under different vegetation eco-restoration models (vegetation concrete eco-restoration technique, frame beam filling soil technique, thick layer base material spraying technique, and external soil spray seeding technique). Vegetation coverage, dominant species, species composition, and species diversity of vegetation community under different vegetation eco-restoration modes were analyzed by field survey. The vegetation community of the abandoned slag slope was unstable due to the simple vegetation community structure. The species and number of the thick layer base material spraying slope were low and fail to form a healthy multilayer community structure due to invade of Leucaena leucocephala (Lam.) de Wit. Studying the allelopathy of Leucaena leucocephala (Lam.) de Wit and seeking the best species composition that can coexist with it is significant to promote the positive succession of the vegetation community. The frame beam filling soil technique, external-soil spray seeding technique, and vegetation concrete eco-restoration technique can effectively promote the succession process of the vegetation community and have well water and soil conservation capacity. These findings suggest that artificial vegetation eco-restoration measures can effectively promote vegetation eco-restoration and the positive succession of vegetation community of disturbed slopes. The research results can provide scientific advice for vegetation eco-restoration and subsequent control and management of disturbed slopes in the Xiangjiaba project, and also can be helpful to other similar projects.
\end{abstract}

\section{INTRODUCTION}

Engineering disturbance can bring serious environmental problems (Ghanbarpour \& Hipel 2009, Cao et al. 2018). However, a large number of hydropower stations have been built because of the demand for clean energy (Zhou \& Chen 2012, Wang et al. 2019, Gyanwali et al. 2020). The construction of a hydropower station changes the surface structure on a large scale and results in vegetation destruction and strong ecosystem disturbance (Sati 2015). Take Xiangjiaba hydropower station as an example, the disturbed area accounts for more than $50 \%$ of the total construction area (Zhou et al. 2016, Xue et al. 2016a). The excavation disturbance results in the original overburden stripping and backfilling disturbance of the slope to form a loose exposed slope body, and the degradation of the slope ecosystem is extremely prominent, which affects the ecological environment and landscape of hydropower development projects ( $\mathrm{Li}$ et al. 2018a). Therefore, it has become a key topic to reconstruct the vegetation of the disturbed slope of hydropower projects on the premise of ensuring the safety of the project (Cao et al. 2010, Xu et al. 2017). Though the instability of slope can be solved by traditional slope treatment methods, it is difficult to restore the natural vegetation and ecosystem functions. Vegetation eco-restoration technology can meet the demands of slope stability and vegetation reconstruction (Xu et al. 2006, Zhao et al. 2017). The vegetation restoration of disturbed slope should be carried out on the premise of fully considering the site conditions and restoration objectives. Healthy vegetation ecosystems are reconstructed by adopting artificial vegetation eco-restoration measures (Alday et al. 2010). A large number of scholars have studied the vegetation restoration of different engineering disturbed slopes from aspects of vegetation restoration technology selection, species allocation model, and vegetation succession law (Chiu 2004, Zhang et al. 2013, Xue et al. 2016b, Chen et al. 2018). The suitability of species for colonization should be taken into account when a plant is selected to use in vegetation restoration. Abiotic conditions, such as soil salinity, soil moisture, hydric stress, and limiting nutrients, could hinder plant establishment of the selected species (Tormo et al. 2006). Both vegetation type and its effect on controlling soil 
erosion should be considered when implementing vegetation restoration (Duan et al. 2016). Matesanz \& Valladares (2007) carried out a multispecies controlled experiment simulating eight different communities with species typically used in the revegetation of gypsum motorways slopes and found that the selection of the species to use in gypsum motorway slopes is crucial for the outcome of the vegetation restoration. Inadequate species selection can render poor results in the long term, and appropriate native species could allow more gradual and stable colonization of the slopes (Matesanz \& Valladares 2007). Bochet \& García-Fayos (2015) built a large database of 296 species 10 traits based on the leaf, seed, and root measurements for selecting suitable species based on morphological and functional plant traits. Vegetation growth can effectively reduce soil erodibility of steep gully slope lands in semi-arid regions, and grassland is more effective than shrub on vegetation-restored gully slope lands on the Loess Plateau (Zhang et al. 2019). Grasses should be prioritized for the improvement of soil conditions during the implementation of vegetation restoration projects in highly fissured areas (Peng et al. 2020). Herbaceous-only vegetation restoration is not suitable for long-term restoration on disturbed slopes, whereas the composition of herbs, shrubs, and trees is a better vegetation construction model for the ecological restoration of disturbed slopes (Li et al. 2018b). To study the vegetation community structure characteristics of the engineering disturbed slope, this study takes the vegetation communities under different vegetation eco-restoration modes in the Xiangjiaba engineering disturbed area as the research object. By analyzing the vegetation community classification, species composition, and species diversity under different vegetation restoration modes, we can understand the structural characteristics of vegetation communities under different vegetation eco-restoration models, reveal the adaptive mechanism of vegetation communities constructed by artificial vegetation eco-restoration techniques to the habitat conditions in the disturbed area of Xiangjiaba project. The research results can provide a theoretical basis for the ecological restoration of the disturbed slope.

\section{MATERIALS AND METHODS}

\section{Description of Experimental Sites}

The study was conducted at Xiangiiaba hydropower station, which is located at the convergence of Sichuan and Yunnan provinces, southeast of China. The experimental sites are in the upper Yangtze River's primary preventative region for soil and water conservation. The area is characterized by a subtropical monsoon climate with an annual average precipitation of $1078 \mathrm{~mm}$, and approximately $90 \%$ of the total precipitation occurs between May and October. We considered typicality in vegetation eco-restoration technique and similarity in evolutionary time when selecting the sites. The selected experimental sites were vegetation concrete eco-restoration slope (VC), frame beam filling soil slope (FB), thick layer base material spraying slope (TB), external-soil spray seeding slope (SS), abandon slag slope (AS), and natural forest (NF). A brief description of the study sites is presented in Table 1 . The unrestored disturbance site (AS) and the undisturbed site (NF) were served as control and used for comparison with those from the disturbed site to determine whether the vegetation eco-restoration technique had an effect on vegetation community characteristics.

\section{Methods of Vegetation Investigation}

The combination of field survey and quadrat sampling method was used to investigate vegetation community in all plots. $5 \mathrm{~m} \times 5 \mathrm{~m}$ quadrats of tree and shrub layer or $1 \mathrm{~m} \times 1 \mathrm{~m}$ quadrats of herb layer were set in every plot according to the types of vegetation, and quadrat was set 5 times repeatedly. The total coverage, name of each plant, fractional coverage, growth forms, average height, and plants numbers were recorded in every quadrat. The important values of different species are calculated according to the results of the quadrat investigation and the related data recorded in every quadrat (Xia 2010, Niu 2013, Liu et al. 2016).

$$
I V=\frac{R H+R F+R C}{3}
$$

Table 1: A brief description of the study sites.

\begin{tabular}{|lllllll|}
\hline Site & Technique & Latitude & Longitude & Altitude $(\mathrm{m})$ & Slope gradient $\left({ }^{\circ}\right)$ & Eco-restoration time \\
\hline VC & Vegetation concrete eco-restoration technique & $28^{\circ} 38^{\prime} \mathrm{N}$ & $104^{\circ} 24^{\prime} \mathrm{E}$ & 328.50 & 63 & 2004.12 \\
FB & Frame beam filling soil technique & $28^{\circ} 38^{\prime} \mathrm{N}$ & $104^{\circ} 24^{\prime} \mathrm{E}$ & 288.9 & 40 & 2004.11 \\
TB & Thick layer base material spraying technique & $28^{\circ} 38^{\prime} \mathrm{N}$ & $104^{\circ} 26^{\prime} \mathrm{E}$ & 388.9 & 51 & 2004.12 \\
SS & External-soil spray seeding technique & $28^{\circ} 39^{\prime} \mathrm{N}$ & $104^{\circ} 23^{\prime} \mathrm{E}$ & 473.9 & 30 & 2005.06 \\
AS & Abandon slag slope & $28^{\circ} 38^{\prime} \mathrm{N}$ & $104^{\circ} 24^{\prime} \mathrm{E}$ & 520.5 & 42 & 502.4 \\
NF & Natural forest & $28^{\circ} 39^{\prime} \mathrm{N}$ & $104^{\circ} 23^{\prime} \mathrm{E}$ & & \\
\hline
\end{tabular}


Where $I V$ is an important value, $R H$ is the ratio of the height of a plant species to the height of all plant species in the quadrat, $R F$ is the ratio of the frequency of a plant species to the frequency of all plant species in the quadrat, $R C$ is the ratio of the coverage of a plant species to the fractional coverage of all plant species in the quadrat. The diversity of the vegetation community is calculated by the following equation in Table 2 (Xia 2010, Niu 2013, Liu et al. 2016).
RESULTS AND DISCUSSION

\section{Coverage and Species Composition of Vegetation Community}

Vegetation coverage is the most visual influence of engineering disturbance on the environment. As shown in Fig. 1, vegetation coverage on the disturbed slope of Xiangjiaba hydropower station changed from $45.0 \%$ to $97.0 \%$. The veg-

Table 2: Formula used to calculate vegetation community diversity index.

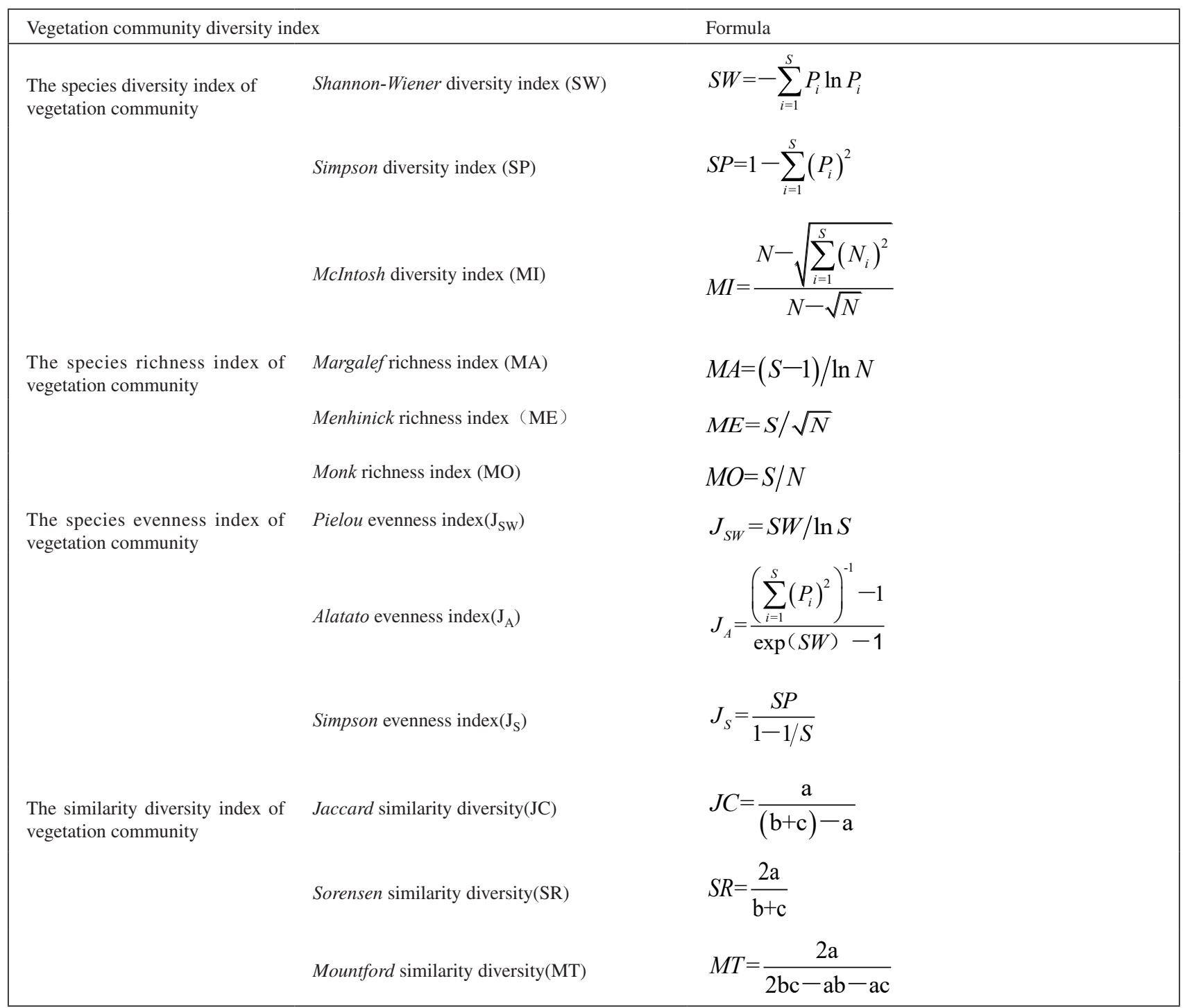

Note: $\mathrm{S}$ is the numbers of plant species in the quadrat, $P_{i}=N_{i} / N$ is the ratio of the individual numbers of species $i$ to the individual numbers of all species, $N_{i}$ is the individual numbers of species $i, \mathrm{~N}$ is the individual numbers of all species in the quadrat, $a$ is the numbers of the same plant species in two quadrants, and $\mathrm{b}$ and $\mathrm{c}$ is the numbers of all plant species in two quadrants. 
etation coverage of FB was $96.1 \%$, which is slightly higher than the vegetation coverage of other artificial sample sites. Based on the statistical analysis of families, genera, and species, the vegetation community in different vegetation eco-restoration modes has been preliminarily analyzed (Table 2). The vegetation community of NF was belonging to 18 families, 22 genera, and 23 species. The vegetation community of AS was a total of 8 families, 14 genera, and

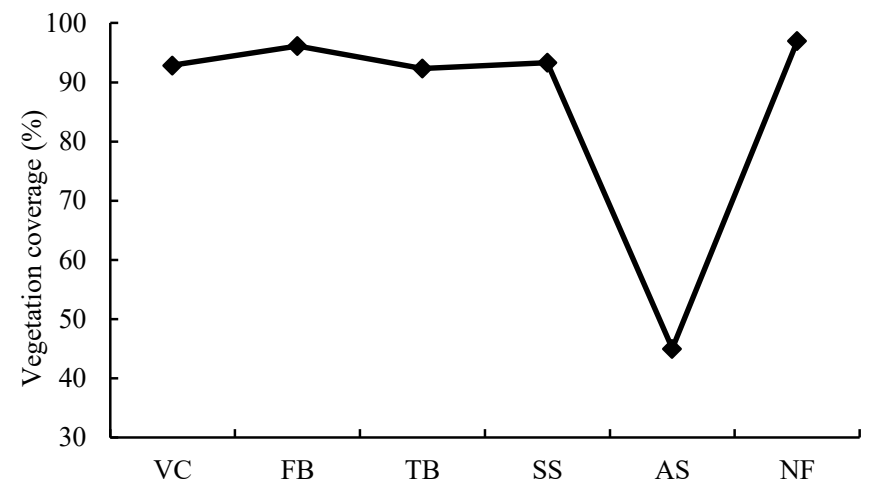

Fig.1: Vegetation coverage in different vegetation eco-restoration modes.

Table 3: Family, genus, and species in different vegetation eco-restoration modes.

\begin{tabular}{|c|c|c|c|c|c|c|c|}
\hline \multirow[t]{2}{*}{ Number } & \multirow[t]{2}{*}{ Latin name } & \multicolumn{6}{|c|}{ Site } \\
\hline & & $\mathrm{VC}$ & $\mathrm{FB}$ & TB & SS & AS & $\mathrm{NF}$ \\
\hline 1 & Liliaceae & & & & & & $1 / 1$ \\
\hline 2 & Plantaginaceae & & & & $1 / 1$ & & \\
\hline 3 & Labiatae & $1 / 1$ & & & $1 / 1$ & & \\
\hline 4 & Euphorbiaceae & & $2 / 2$ & & & & \\
\hline 5 & Aquifoliaceae & & & & & & $1 / 1$ \\
\hline 6 & Leguminosae & $4 / 4$ & $4 / 4$ & $3 / 3$ & $2 / 2$ & & $2 / 2$ \\
\hline 7 & Pteridaceae & & & $1 / 1$ & & & \\
\hline 8 & Lygodium & & $1 / 1$ & $1 / 1$ & $1 / 1$ & & $1 / 1$ \\
\hline 9 & Gramineae & $4 / 4$ & $10 / 11$ & $3 / 3$ & $5 / 5$ & $4 / 4$ & $2 / 2$ \\
\hline 10 & Betulaceae & & & & & & $1 / 1$ \\
\hline 11 & Malvaceae & & $1 / 1$ & & & & \\
\hline 12 & Compositae & $1 / 1$ & $6 / 6$ & & $3 / 3$ & $3 / 3$ & \\
\hline 13 & Fagaceae & & & & & & $1 / 1$ \\
\hline 14 & Gesneriaceae & & $1 / 1$ & & $1 / 1$ & $1 / 1$ & \\
\hline 15 & Gleicheniaceae & & & & $1 / 1$ & & $1 / 1$ \\
\hline 16 & Malvaceae & & $1 / 1$ & & & & \\
\hline 17 & Polygonaceae & & & & $1 / 1$ & & \\
\hline 18 & Lindsaeaceae & & & & & & $1 / 1$ \\
\hline 19 & Asclepiadaceae & & $1 / 1$ & & & & \\
\hline 20 & Verbenaceae & $2 / 2$ & $2 / 2$ & & & & \\
\hline 21 & Loganiaceae & & $1 / 1$ & & & & \\
\hline 22 & Ranunculaceae & & & & & & $1 / 1$ \\
\hline 23 & Equisetaceae & & & & $1 / 1$ & & \\
\hline
\end{tabular}

Table cont.... 


\begin{tabular}{|c|c|c|c|c|c|c|c|}
\hline \multirow[t]{2}{*}{ Number } & \multirow[t]{2}{*}{ Latin name } & \multicolumn{6}{|c|}{ Site } \\
\hline & & $\mathrm{VC}$ & FB & $\mathrm{TB}$ & SS & AS & $\mathrm{NF}$ \\
\hline 24 & Lythraceae & & & & $1 / 1$ & & \\
\hline 25 & Rosaceae & & $1 / 1$ & & $1 / 1$ & & $2 / 2$ \\
\hline 26 & Solanaceae & & $1 / 1$ & & & & \\
\hline 27 & Caprifoliaceae & & & & & & $1 / 1$ \\
\hline 28 & Umbelliferae & & $1 / 1$ & & $1 / 1$ & & \\
\hline 29 & Moraceae & $1 / 1$ & $3 / 3$ & $1 / 1$ & & $1 / 1$ & \\
\hline 30 & Cyperaceae & & & & & & $1 / 1$ \\
\hline 31 & Theaceae & & & & & & $2 / 3$ \\
\hline 32 & Phytolaccaceae & $1 / 1$ & & & & & \\
\hline 33 & Pinaceae & & & & & & $1 / 1$ \\
\hline 34 & Oleandracea & & $1 / 1$ & $1 / 1$ & $1 / 1$ & $1 / 1$ & \\
\hline 35 & Amaranthaceae & $1 / 2$ & $1 / 1$ & & & $2 / 2$ & \\
\hline 36 & Scrophulariaceae & & & & & $1 / 1$ & $1 / 1$ \\
\hline 37 & Urticaceae & & $1 / 1$ & & & & \\
\hline 38 & Commelinaceae & & $1 / 1$ & & & & \\
\hline 39 & Rutaceae & & & & & $1 / 1$ & $1 / 1$ \\
\hline 40 & Lauraceae & & & & & & $1 / 1$ \\
\hline 41 & Oxalidaceae & & $1 / 1$ & & $1 / 1$ & & \\
\hline \multicolumn{2}{|c|}{ Total (family) } & 8 & 20 & 6 & 15 & 8 & 18 \\
\hline \multicolumn{2}{|c|}{ Total (genus) } & 15 & 41 & 10 & 22 & 14 & 22 \\
\hline \multicolumn{2}{|c|}{ Total (species) } & 16 & 42 & 10 & 22 & 14 & 23 \\
\hline
\end{tabular}

15 species, and much simpler than NF. The FB had the most plant species in artificial vegetation eco-restoration sites and totaled 20 families, 41 genera, and 42 species, and $40 \%$ of the total number of species were Gramineae and Compositae. The TB had the simplest species, and belonging to 6 families, 10 genera, and 10 species. And the dominant species were Gramineae and Leguminosae, making up for $60 \%$ of the total species.

\section{Growth Forms of Vegetation Community}

The growth forms of vegetation community under different vegetation eco-restoration modes were shown in Fig. 2 and classified by trees, shrubs, lianas, perennial herbs, and annual herbs or biennial herbs. Growth forms of different vegetation eco-restoration modes were different significantly. Perennial herbs and shrubs accounted for $43.75 \%$ and $31.25 \%$ of the vegetation community in $\mathrm{VC}$, respectively. Perennial herbs accounted for $42.86 \%$ of the vegetation community in FB. The growth forms of the vegetation community in $\mathrm{VC}$ and FB were diverse and included all five growth forms. There were only trees, perennial herbs, and annual herbs or biennial herbs, and herbs were dominant and accounted for $78.57 \%$ of total species in AS. There were trees, shrubs, perennial herbs, and annual herbs or biennial herbs in TB, and the quantities of trees, shrubs, and annual herbs or biennial herbs were almost equal. There were only trees, shrubs, perennial herbs, and annual herbs or biennial herbs in SS. Perennial herbs were dominant and accounted for $59.09 \%$ of the total species, and trees and lianas only accounted for $9.09 \%$ in total. Trees and shrubs were dominant in NF, and shrubs, trees, and perennial herbs accounted for $34.78 \%, 30.43 \%$, and $26.09 \%$, respectively.

\section{Important Value of Plant Species}

As shown in Table 4, the species composition of vegetation communities in different vegetation eco-restoration modes was surveyed, and vegetation species of all plots were 87 in total. Plant species composition and dominant species were obviously different. Some initial herb species disappeared gradually in $\mathrm{VC}, \mathrm{FB}$, and $\mathrm{SS}$, and the importance value of some alien invasive species was increasing, especially some trees, shrubs, and lianas, and the vegetation community began to change from herb layer to herbs-shrubs-lianas layer. The dominant species of TB was Leucaena leucocephala (Lam.) 
de Wit with an importance value of $57.14 \%$. Some initial species in TB disappeared gradually, such as Festuca elata Keng ex E. Alexeev, Medicago sativa L., and Cynodondactylon (Linn.)Pers. The importance values of invasive species Broussonetia papyrifera (L.) L'Hér. ex Vent. and Sophora xanthantha C. Y. Ma was $9.46 \%$ and $5.61 \%$, respectively. The important value of dominant species Alnus cremastogyne Burk. was $12.21 \%$ in NF.

\section{The Diversity Indexes of Vegetation Community}

As shown in Fig. 3, the species diversity index of vegetation communities in different vegetation eco-restoration modes was different, but the highest value of species diversity indexes appeared in NF. The lowest Shannon-Wiener diversity index appeared in VC. The changing trend of the McIntosh diversity index and Simpson diversity index were similar in all plots. The lowest species diversity index occurred in AS.
The change trends of species richness indexes of all plots were basically identical (Fig. 4). The highest value of the Margalef diversity index and Menhinick diversity index appeared in FB, and the lowest value of the Margalef diversity index and Menhinick diversity index appeared in TB. The Monk diversity index of NF (0.223) was the highest, and the Monk diversity index of TB (0.075) was the lowest. Simpson evenness index and Alatato evenness index in NF were both the highest, but Simpson evenness index and Alatato evenness index of the abandon slag slope (AS) were both the lowest (Fig. 5). The Pielou evenness index of NF was the highest (0.923), and the Pielou evenness index of VC was the lowest (0.498). As shown in Table 5, the range of Jaccard similarity index, Sorensen similarity index, and Mountford similarity index was $0.000 \sim 0.244,0.000 \sim 0.393$, and 0.000 0.043 respectively. The lowest size of the three similarity indexes all appeared between $\mathrm{VC}$ and NF.

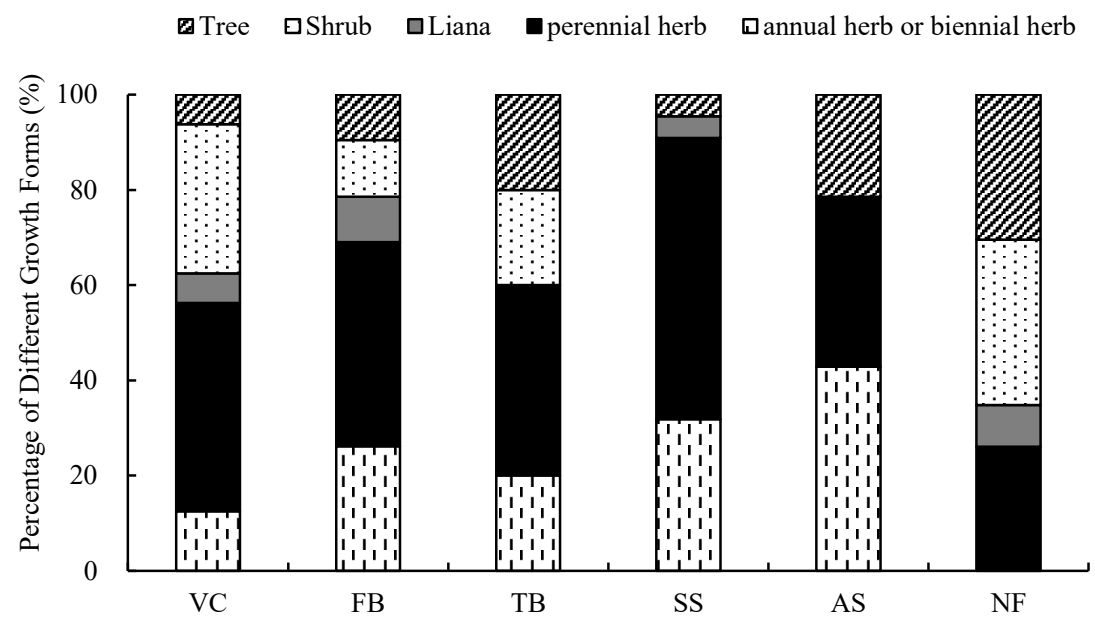

Fig. 2: Growth forms of vegetation community in different vegetation eco-restoration modes.

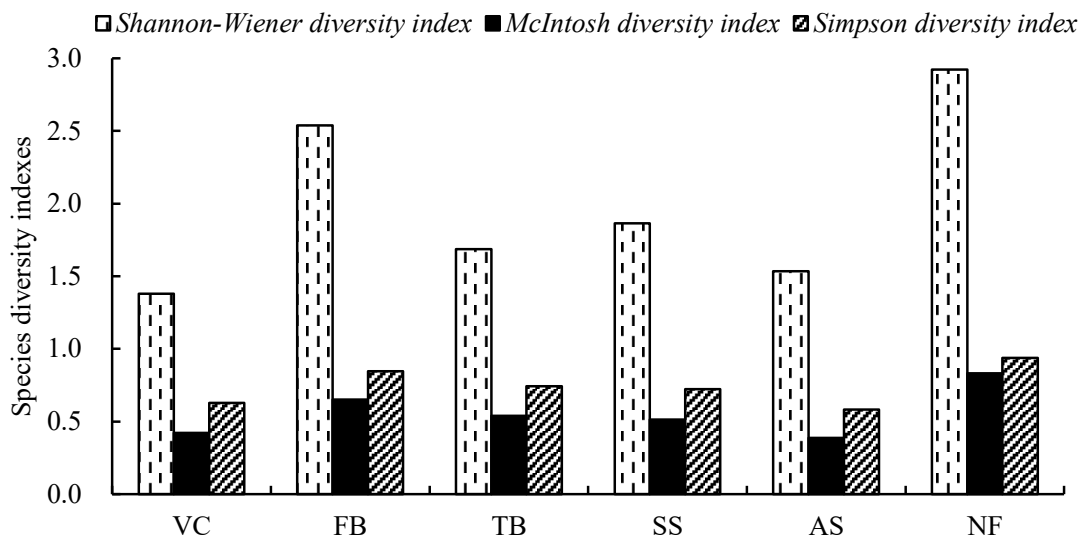

Fig. 3: Species diversity indexes of vegetation community in different vegetation eco-restoration modes. 


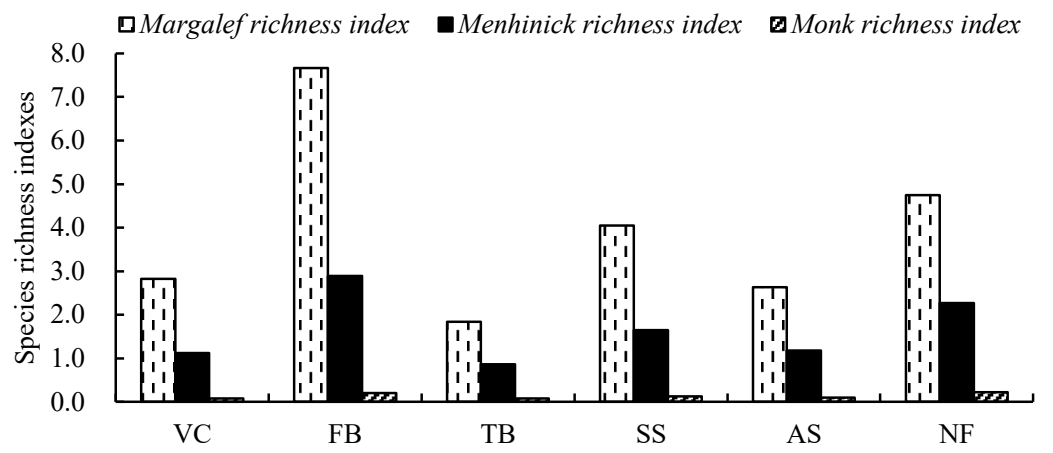

Fig. 4: Species richness indexes of vegetation community in different vegetation eco-restoration modes.

\section{DISCUSSION}

Vegetation community characteristics can be used as a measuring index to describe the process of vegetation restoration (Wang et al. 2012). And according to a large number of studies, vegetation community characteristics include vegetation coverage, species composition, dominant species, and species diversity (Ding \& Zang 2005, Ruiz-Jaen \& Aide 2010, Wortley et al. 2013). Vegetation coverage is an important index to evaluate the growth status of vegetation communities and the ability of conservation of soil and water, and low vegetation coverage is easier to lead to soil erosion than high vegetation coverage (Yuan et al. 2016, Chen et al. 2019). There was a litter difference between artificial vegetation eco-restoration plots in vegetation coverage, which basically reached the level of vegetation coverage of NF. However, there were differences in community species composition among various plots. Species composition is an important index to describe community characteristics (Ding $\&$ Zang 2005). The number of species in FB (20 families, 41 genera, and 42 species) increased greatly compared to AS, but the plants were primarily herb and accounted for $69.05 \%$ of the total species. The species composition among artificial vegetation eco-restoration plots was different but was dominant by perennial plants all, and vegetation community structure began to change from herb layer to herbs-shrubs-lianas layer mixed. Perennial plants being dominant, especially the trees and shrubs showed that the vegetation community is stable (Fike \& Niering 1999). The important value of the dominant species reflects the complexity of vegetation community structure, and dominant species influence both species and functional composition of the vegetation community (Kompala-Baba et al. 2020). The important value of a dominant species called Leucaena leucocephala (Lam.) de Wit was far higher than other accompanying species in TB, which showed that the complexity of vegetation community structure was low. The invasive plants can affect native plants by producing allelochemicals (Mignoni et al. 2017).

The $\alpha$ diversity is an important index to describe community characteristics, which include species diversity indexes, species richness index, and species evenness index (Zhang et al. 2005, Wang et al. 2006). The $\alpha$ diversity level of vegetation community was discussed from three aspects: the number of species, the individual difference of species, and the evenness of species distribution (Zhang et al. 2005,

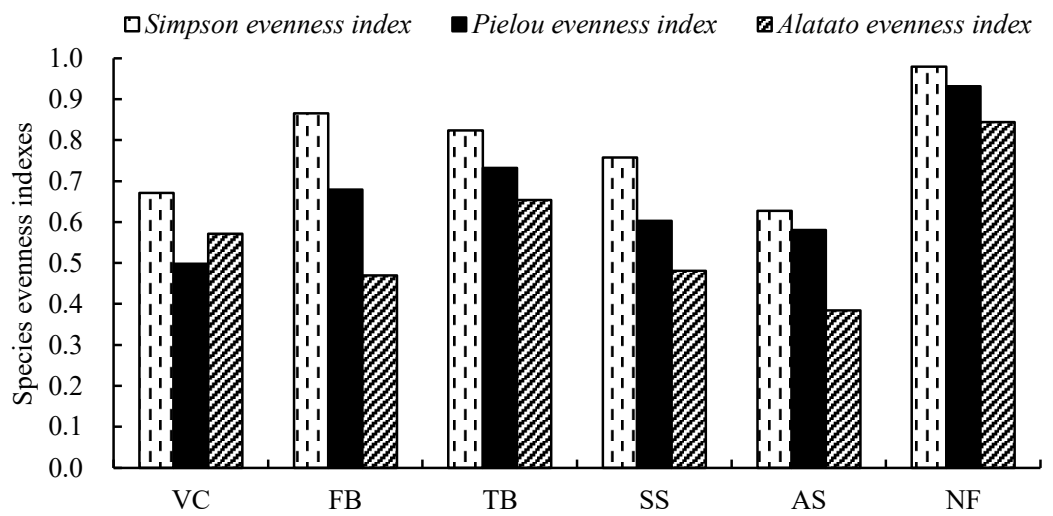

Fig. 5: Species evenness indexes of vegetation community in different vegetation eco-restoration modes. 
Table 4: Species composition and important value of vegetation community in different vegetation eco-restoration modes.

\begin{tabular}{|c|c|c|c|c|c|c|c|}
\hline \multirow[t]{2}{*}{ Number } & \multirow[t]{2}{*}{ Latin name } & \multicolumn{6}{|c|}{$I V(\%)$} \\
\hline & & $\mathrm{VC}$ & FB & TB & SS & AS & $\mathrm{NF}$ \\
\hline 1 & Artemisia argyi Levl. et Van. & & 4.42 & & & 4.72 & \\
\hline 2 & Smilax china & & & & & & 1.33 \\
\hline 3 & Imperata cylindrica (L.) Beauv. & & 11.47 & & 15.49 & 3.98 & \\
\hline 4 & Saccharum arundinaceum Retz. & 4.30 & & & & & \\
\hline 5 & Plantago depressa Willd. & & & & 1.96 & & \\
\hline 6 & Clerodendrum bungei Sterd. & 2.88 & 1.23 & & & & \\
\hline 7 & Solanum torvum Swartz & & 1.00 & & & & \\
\hline 8 & Euphorbia humifusa Willd. ex Schlecht. & & 0.59 & & & & \\
\hline 9 & Ilex chinensis Sims & & & & & & 4.25 \\
\hline 10 & Indigofera amblyatha & 6.49 & & & & & \\
\hline 11 & Commelina bengalensis & & 0.93 & & & & \\
\hline 12 & Urena procumbens Linn. & & 1.50 & & & & \\
\hline 13 & Pteris cretica Linn. var. nervossa (Thunb.)Ching et S.H.Wu & & & 5.57 & & & \\
\hline 14 & Festuca elata Keng ex E. Alexeev & & & & 6.89 & & \\
\hline 15 & Pueraria lobata (Willdenow) Ohwi & 8.74 & 3.26 & & 5.23 & & \\
\hline 16 & Setaria viridis (L.) Beauv. & & 1.11 & & & 15.66 & \\
\hline 17 & Broussonetia papyrifera (L.) L'Hér. ex Vent. & 7.68 & 4.58 & 9.46 & & 6.50 & \\
\hline 18 & Lygodium japonicum (Thunb.)Sw. & & 3.81 & 3.42 & 1.82 & & 1.19 \\
\hline 19 & Albizia julibrissin Durazz. & & & & & & 6.55 \\
\hline 20 & Polygonum orientale $\mathrm{L}$. & & & & 2.93 & & \\
\hline 21 & Lespedeza bicolor Turcz. & 2.94 & & 4.73 & & & \\
\hline 22 & Zanthoxylum bungeanum Maxim. & & & & & 10.75 & \\
\hline 23 & Artemisia аппиа & & & & 3.72 & & \\
\hline 24 & Sophora xanthantha C. Y. Ma & 2.46 & & 5.61 & & & \\
\hline 25 & Themeda villosa (Poir.) A. Camus & & 1.13 & & & & \\
\hline 26 & Pogonatherum crinitum (Thunb.) Kunth & & & & 2.28 & & \\
\hline 27 & Lonicera japonica Thunb. & & & & & & 1.59 \\
\hline 28 & Arthraxon hispidus (Thunb.) Makio & 11.81 & 7.83 & 4.95 & 3.39 & 3.86 & \\
\hline 29 & Citrus reticulata & & & & & & 1.87 \\
\hline 30 & Alternanthera philoxeroides & 1.69 & & & & & \\
\hline 31 & Conandron ramondioides $\mathrm{S}$. et $\mathrm{Z}$. & & 0.86 & & 2.90 & 2.49 & \\
\hline 32 & Melia azedarach Linn. & & 3.41 & & & & \\
\hline 33 & Pennisetum alopecuroides (L.) Spreng. & 25.61 & 1.42 & & & & \\
\hline 34 & Diplopterygium glaucum (Thunb. ex Houtt.) Nakai & & & & 7.08 & & 2.49 \\
\hline 35 & Quercus mongolica Fisch. ex Ledeb. & & & & & & 4.92 \\
\hline 36 & Arundo donax & 4.19 & & & & & \\
\hline 37 & Metaplexis japonica (Thunb.) Makino & & 1.45 & & & & \\
\hline 38 & Humulus japonicus & & 0.64 & & & & \\
\hline 39 & Digitaria sanguinalis (L.) Scop. & & 1.68 & 4.31 & 1.91 & 2.74 & \\
\hline 40 & Pinus massoniana Lamb. & & & & & & 6.96 \\
\hline 41 & Alternanthera sessilis (L.) DC. & 3.64 & 1.98 & & & 5.58 & \\
\hline 42 & Miscanthus sinensis Anderss. & & 1.52 & & & & 1.59 \\
\hline 43 & Paulownia tomentosa (Thunb.) Steud. & & & & & 7.55 & 7.09 \\
\hline 44 & Vitex negundo L. & 9.39 & 0.91 & & & & \\
\hline 45 & Eleusine indica (L.) Gaertn. & & 0.63 & & & & \\
\hline 46 & Rubus hirsutus Thunb. & & & & & & 3.35 \\
\hline
\end{tabular}




\begin{tabular}{|c|c|c|c|c|c|c|c|}
\hline \multirow[t]{2}{*}{ Number } & \multirow[t]{2}{*}{ Latin name } & \multicolumn{6}{|c|}{$I V(\%)$} \\
\hline & & $\mathrm{VC}$ & FB & $\mathrm{TB}$ & SS & AS & $\mathrm{NF}$ \\
\hline 47 & Ficus tikoua Bur. & & 0.93 & & & & \\
\hline 48 & Alnus cremastogyne Burk. & & & & & & 12.21 \\
\hline 49 & Leptochloa chinensis (L.) Nees & & 1.17 & & & & \\
\hline 50 & Senecio scandens Buch.-Ham. ex D. Don & & & & 2.65 & & \\
\hline 51 & Carex breviculmis $\mathrm{R}$. Br. & & & & & & 2.52 \\
\hline 52 & Celosia argentea $\mathrm{L}$. & & & & & 3.57 & \\
\hline 53 & Oplismenus undulatifolius (Arduino) Beauv. & & & 9.54 & & & \\
\hline 54 & Bidens pilosa Linn. & & 2.89 & & & 5.28 & \\
\hline 55 & Camellia japonica $\mathrm{L}$. & & & & & & 5.18 \\
\hline 56 & Lindera glauca (Sieb. et Zucc.) B1 & & & & & & 5.76 \\
\hline 57 & Phytolacca acinosa Roxb. & 2.76 & & & & & \\
\hline 58 & Cnidium monnieri (L.) Cuss. & & 0.90 & & & & \\
\hline 59 & Nephrolepis cordifolia (L.)Presl & & 2.03 & 3.84 & 1.91 & 3.54 & \\
\hline 60 & Mosla scabra (Thunb.) C. Y. Wu et H. W. Li & 2.32 & & & & & \\
\hline 61 & Hydrocotyle sibthorpioides Lam. & & & & 2.31 & & \\
\hline 62 & Sesbania cannabina (Retz.) Poir. & & 1.53 & & 2.37 & & \\
\hline 63 & Potentilla chinensis Ser. & & & & 2.00 & & \\
\hline 64 & Equisetum arvense $\mathrm{L}$. & & & & 2.23 & & \\
\hline 65 & Sapium sebiferum (L.) Roxb. & & 2.71 & & & & \\
\hline 66 & Sphenomeris chinensis (L.) Maxon & & & & & & 2.72 \\
\hline 67 & Miscanthus floridulus (Lab.) Warb. ex Schum. et Laut. & & 1.80 & & & & \\
\hline 68 & Capillipedium parviflorum (R. Br.) Stapf. & & 9.73 & & & & \\
\hline 69 & Eurya nitida Korthals & & & & & & 2.65 \\
\hline 70 & Prunella vulgaris L. & & & & 1.82 & & \\
\hline 71 & Conyza canadensis (L.) Cronq. & & 4.01 & & 2.77 & 5.45 & \\
\hline 72 & Boehmeria spicata (Thunb.) Thunb. & & 2.55 & & & & \\
\hline 73 & Cirsium setosum (Willd.) MB. & & 1.21 & & & & \\
\hline 74 & Leucaena leucocephala (Lam.) de Wit & & & 57.14 & & & \\
\hline 75 & Rosa rubus Lévl. et Vant. & & 2.16 & & & & \\
\hline 76 & Paeonia delavayi Franch. & & & & & & 3.65 \\
\hline 77 & Rosa multiflora Thunb. & & & & & & 2.76 \\
\hline 78 & Erigeron anпииs (L.) Pers. & & 0.69 & & & & \\
\hline 79 & Camellia oleifera Abel. & & & & & & 3.73 \\
\hline 80 & Caesalpinia decapetala (Roth) Alston & & 1.30 & & & & \\
\hline 81 & Crotalaria pallida Ait. & & 0.77 & & & & \\
\hline 82 & Oplismenus compositus (L.) Beauv. & & & & & & 2.83 \\
\hline 83 & Eupatorium coelestinum $\mathrm{L}$. & 3.09 & 1.30 & & & & \\
\hline 84 & Wisteria sinensis & & & & & & 4.46 \\
\hline 85 & Lagerstroemia indica $\mathrm{L}$. & & & & 22.90 & & \\
\hline 86 & Buddleja lindleyana & & 3.15 & & & & \\
\hline 87 & Oxalis corniculata Linn. & & 0.78 & & 1.21 & & \\
\hline
\end{tabular}

Liu 2015). As a result of the positive succession of the vegetation community, the $\alpha$ diversity increased. (Wang et al. 2006). The results of the $\alpha$ diversity indexes embody the structure and complex degree of vegetation community, and artificial vegetation eco-restoration patterns can promote the recovery of vegetation community effectively (Pueyo et al.
2006). The $\beta$ diversity indexes of vegetation communities focus on reflecting the different degrees of species structure and composition among different vegetation communities and expressing heterogeneity among communities (Han et al. 2009). Results of this study showed that species composition among all plots was different, especially between 
Table 5: Species similarity indexes among vegetation communities in different vegetation eco-restoration modes.

\begin{tabular}{|c|c|c|c|}
\hline \multirow[t]{2}{*}{ Site } & \multicolumn{3}{|c|}{ Species similarity indexes } \\
\hline & Jaccard similarity index & Sorensen similarity index & Mountford similarity index \\
\hline VC-FB & 0.160 & 0.276 & 0.018 \\
\hline VC-TB & 0.182 & 0.308 & 0.037 \\
\hline VC-SS & 0.056 & 0.105 & 0.006 \\
\hline VC-AS & 0.111 & 0.200 & 0.017 \\
\hline VC-NF & 0.000 & 0.000 & 0.000 \\
\hline FB-TB & 0.106 & 0.192 & 0.017 \\
\hline FB-SS & 0.185 & 0.313 & 0.017 \\
\hline FB-AS & 0.244 & 0.393 & 0.039 \\
\hline FB-NF & 0.032 & 0.062 & 0.002 \\
\hline TB-SS & 0.143 & 0.250 & 0.026 \\
\hline TB-AS & 0.200 & 0.333 & 0.043 \\
\hline TB-NF & 0.031 & 0.061 & 0.005 \\
\hline SS-AS & 0.200 & 0.333 & 0.030 \\
\hline SS-NF & 0.047 & 0.089 & 0.004 \\
\hline AS-NF & 0.028 & 0.054 & 0.003 \\
\hline
\end{tabular}

$\mathrm{NF}$ and artificial vegetation eco-restoration plots, and the disturbed vegetation community needs a long time to return to the natural level.

Decrease or even loss of soil and water conservation function is a prominent problem of engineering disturbed slope while increasing the surface vegetation coverage is the most direct and effective method to control soil erosion (El Kateb et al. 2013, Wang et al. 2016). Numerous studies have shown that community structure with primary near-surface herbs can effectively intercept rainfall and weaken the role of rainwater erosion through the interception precipitation and extend infiltration time to reduce slope runoff (Zhou \& Shangguan 2008, Du et al. 2017, Zhang et al. 2017, Gao et al. 2020). Vegetation coverage of the four artificial vegetation eco-restoration sample sites increased obviously than AS, especially in VC and FB which herbaceous were main dominant species. Therefore, it can be considered that the vegetation concrete eco-restoration technology, the frame beam filling soil technology, and the external-soil spray seeding technology can improve soil and water conservation function of engineering disturbed slope effectively. In TB, Leucaena leucocephala (Lam.) de Wit resulted in the species and quantity of vegetation community is low, and fail to form the healthy multilayer community structure. Therefore, the surface vegetation coverage of TB was much lower than the other three artificial vegetation eco-restoration sample sites. Studying the allelopathy of Leucaena leucocephala (Lam.) de Wit and seeking the best species composition that can coexist with it is significant to promote the positive succession of the vegetation community in TB. It is also of great significance to improve the soil and water conservation function of the disturbed slope.

\section{CONCLUSIONS}

The results of field investigation and analysis undertaken in disturbed slopes at Xiangjiaba hydropower station have revealed that there was a big difference in vegetation community characteristics between different vegetation eco-restoration modes. The vegetation coverage, species numbers, growth type composition, and family, genus, and species of vegetation community of AS were significantly lower than that of artificial vegetation eco-restoration slopes and NF. The simple vegetation community structure indicates that the vegetation community of AS was unstable. The absolute advantage of the two perennial plants indicates that the vegetation community of $\mathrm{VC}$ is in a stable state. The species and number of TB were low and fail to form a healthy multilayer community structure due to the invasion of Leucaena leucocephala (Lam.) de Wit. It is significant to study the allelopathy of Leucaena leucocephala (Lam.) de Wit and seek the best species composition that can coexist with it. The frame beam filling soil technique, external-soil spray seeding technique, and vegetation concrete eco-restoration technique can effectively promote the succession process of the vegetation community. And the absolute advantage of herbs in FB, SS, and VC can also prove that these three techniques have good water and soil conservation capacity. 


\section{ACKNOWLEDGMENTS}

This research was supported by the CRSRI Open Research Program (CKWV2019763/KY), the National Focal Research Program of China (2017YFC0504902), and the National Natural Science Foundation of China (51979147).

\section{REFERENCES}

Alday, J.G., Marrs, R.H. and Martínez-Ruiz, C. 2010. The importance of topography and climate on short-term revegetation of coal wastes in Spain. Ecol. Eng., 36(4): 579-585.

Bochet, E. and García-Fayos, P. 2015. Identifying plant traits: A key aspect for species selection in the restoration of eroded roadsides in semiarid environments. Ecol. Eng., 83: 444-451.

Cao, S.X., Xu, C.L., Ye, H.H., Zhan, Y. and Gong, C. 2010. The use of air bricks for planting roadside vegetation: A new technique to improve the landscaping of steep roadsides in China's Hubei Province. Ecol. Eng., 36(5): 697-702.

Cao, W., Omran, B.A., Lei, Y.K., Zhao, X., Yang, X.M., Chen, Q. and Tian, G.H. 2018. Studying early-stage slope protection effects of vegetation communities for Xinnan Highway in China. Ecol. Eng., 110: 87-98.

Chen, J., Xiao, H.B., Li, Z.W., Liu, C., Wang, D.Y., Wang, L.X. and Tang, C.J. 2019. Threshold effects of vegetation coverage on soil erosion control in small watersheds of the red soil hilly region in China. Ecol. Eng., 132: 109-114.

Chen, W., Chen, Y. and Yang, S. 2018. Optimization of Slope Vegetation System Based on Entropy Method and Relative Entropy Evaluation Method. Bull. Soil Water Conser., 38(2): 313-317 (In Chinese).

Chiu, P.K.B. 2004. Slope bioengineering in Hong Kong: A study of substrate properties and vegetation development. The Chinese University of Hong Kong (In Chinese).

Ding, Y. and Zang, R.G. 2005. Community characteristics of early recovery vegetation on abandoned lands of shifting cultivation in Bawangling of Hainan Island, South China. Journal of Integrative Plant Biology, 47(5): 530-538.

Du, X.Y., Liang, Y.Z., Xia, Z.Y., Xia, D., X, W.N. and Wang, Y.K. 2017. Soil nutrient loss characteristic of gravel soil slope on different vegetation patterns. J. Soil Water Cons., 31(1): 61-67 (In Chinese).

Duan, L.X., Huang, M.B. and Zhang, L.D. 2016. Differences in hydrological responses for different vegetation types on a steep slope on the Loess Plateau, China. J. Hydrol., 537: 356-366.

El Kateb, H., Zhang, H.F., Zhang, P.C. and Mosandl, R. 2013. Soil erosion and surface runoff on different vegetation covers and slope gradients: A field experiment in Southern Shaanxi Province, China. Catena, 105: 1-10.

Fike, J. and Niering, W. A. 1999. Four decades of old-field vegetation development and the role of Celastrus orbiculatus in the northeastern United States. J. Veg. Sci., 10(4): 483-492.

Gao, J.B., Jiang, Y., Wang, H. and Zuo, L.Y. 2020. Identification of dominant factors affecting soil erosion and water yield within ecological red line areas. Rem. Sens., 12(3): 399.

Ghanbarpour, M.R. and Hipel, K.W. 2009. Sustainable development conflict over freeway construction. Environ. Dev. Sustain., 11(2): 241-253.

Gyanwali, K., Komiyama, R. and Fujii, Y. 2020. Representing hydropower in the dynamic power sector model and assessing clean energy deployment in the power generation mix of Nepal. Energy, 11: 77-95.

Han, D. Y., Li, H.Y. and Yang, Y.F. 2009. - -diversity patterns of plant community in fragmented habitat in a degenerated meadow in Songnen Plain, China. Chinese Geographical Science, 19(4): 375-381.

Kompala-Baba, A., Sierka, E., Dyderski, M.K., Bierza, W. and Woniak, G. 2020. Do the dominant plant species impact the substrate and vegetation composition of post-coal mining spoil heaps? Ecol. Eng., 143, 105685.
Li, B., Li, T., Xu, N.W., Dai, F., Chen, W.F. and Tan, Y.S. 2018a. Stability assessment of the left bank slope of the Baihetan Hydropower Station, Southwest China. Int. J. Rock Mech. Min. Sci., 104: 34-44.

Li, R.R., Kan, S.S., Zhu, M.K., Chen, J., Ai, X.Y., Chen, Z.Q., Z, J.J. and Ai, Y.W. 2018b. Effect of different vegetation restoration types on fundamental parameters, structural characteristics, and the soil quality index of artificial soil. Soil Till. Res., 184: 11-23.

Liu, X.Q., Zhang, X., Zhang, L.F., Li, Y. N., Zhao, L., Xu, S.X., Li, H.Q., Ma, R.R., Niu, B., Gao, Y.B. and Gu, S. 2016. Effects of exclosure duration on the community structure and species diversity of an alpine meadow in the Qinghai-Tibet Plateau. Acta Ecologica Sinica, 36(16): 5150-5162 (In Chinese).

Liu, Y. 2015. Plant Diversity and Ecosystem Multifunctionality in Constructed Wetlands. Zhejiang University (In Chinese).

Matesanz, S. and Valladares, F. 2007. Improving revegetation of gypsum slopes is not a simple matter of adding native species: Insights from a multispecies experiment. Ecol. Eng., 30(1): 67-77.

Mignoni, D.S.B., Simões, K. and Braga, M.R. 2017. Potential allelopathic effects of the tropical legume Sesbania virgata on the alien Leucaena leucocephala related to seed carbohydrate metabolism. Biol. Invas., 20(1): 165-180.

Niu, X. 2013. Studies on Revegetation and Restoration Effects of Yimin Opencast Mining Wasteland. Inner Mongolia Agricultural University (In Chinese).

Peng, X.D., Dai, Q.H., Ding, G.J., Shi, D.M. and Li, C.L. 2020. Impact of vegetation restoration on soil properties in near-surface fissures located in karst rocky desertification regions. Soil and Till. Res., 200: 104620.

Pueyo, Y., Alados, C.L. and Ferrer-Benimeli, C. 2006. Is the analysis of plant community structure better than common species-diversity indices for assessing the effects of livestock grazing on a Mediterranean arid ecosystem? J. Arid Environ., 64(4): 698-712.

Ruiz-Jaen, M.C. and Aide, T.M. 2010. Restoration success: How is it being measured? Restor. Ecol., 13(3): 569-577.

Sati, V.P. 2015. Landscape vulnerability and rehabilitation issues: a study of hydropower projects in Garhwal region, Himalaya. Nat. Hazards, 75(3): 2265-2278.

Tormo, J., Bochet, E. and García-Fayos, P. 2006. Is seed availability enough to ensure colonization success? An experimental study in road embankments. Ecol. Eng., 26(3): 224-230.

Wang, L., Wang, Y., Du, H.B., Zuo, J., Li, R.Y.M., Zhou, Z.H., Bi, H.H. and Garvlehn, M.P. 2019. A comparative life-cycle assessment of hydro-, nuclear and wind power: A China study. Appl. Energy, 249: 37-45.

Wang, W.Y., Wang, Q.J. and Wang, H.C. 2006. The effect of land management on plant community composition, species diversity, and productivity of alpine Kobersia steppe meadow. Ecol. Res., 21(2): 181-187.

Wang, X.D., Yu, J.B., Zhou, D., Dong, H.F., Li, Y.Z., Lin, Q.X., Guan, B. and Wang, Y.L. 2012. Vegetative ecological characteristics of restored reed (Phragmites australis) wetlands in the Yellow River Delta, China. Environ. Manag., 49(2): 325-333.

Wang, Z.J., Jiao, J.Y., Rayburg, S., Wang, Q.L. and Su, Y. 2016. Soil erosion resistance of "Grain for Green" vegetation types under extreme rainfall conditions on the Loess Plateau, China. Catena, 141: 109-116.

Wortley, L., Hero, J.M. and Howes, M. 2013. Evaluating ecological restoration success: A review of the literature. Restor. Ecol., 21(5): 537-543.

Xia, Z.Y. 2010. Earlier Succession and Stability of Artificial Vegetation Community on Disturbed Slope in Xiangjiaba Hydropower Station. Wuhan University (In Chinese).

Xu, W.N., Xia, D., Zhao, B.Q., Xia, Z.Y., Liu, D.X. and Zhou, M. T. 2017. Research on Slope Eco-Restoration Technique for Hydroelectric Projects Disturbed Area. Science Press, Beijing (In Chinese).

Xu, X.L., Zhang, K.L., Kong, Y.P., Chen, J.D. and Yu, B.F. 2006. Effectiveness of erosion control measures along the Qinghai-Tibet highway, Tibetan plateau, China. Transp. Res. D Trans. Environ., 11(4): 302-309. Xue, H.L., Xu, W.N. and Liu, D.X. 2016a. Changes of soil fertility and 
enzyme activity on different standing conditions under two slope ecological restoration patterns. Bull. Soil Water Conserv., 36(4): 182187 (In Chinese).

Xue, O., Wei, T.X., Liu, F. and Li, Y.Y. 2016b. Modeling the degree of coupling and interaction between plant community diversity and soil properties on highway slopes. J. Beijing Forestry Univ., 38(1): 91-100 (In Chinese).

Yuan, Z.Q., Yu, K.L., Epstein, H., Fang, C., Li, J.T., Liu, Q.Q., Liu, X.W., Gao, W.J. and Li, F.M. 2016. Effects of legume species introduction on vegetation and soil nutrient development on abandoned croplands in a semi-arid environment on the Loess Plateau, China. Sci. Total Environ., 541: 692-700

Zhang, B.J., Zhang, G.H., Yang, H.Y. and Wang, H.Y. 2019. Soil resistance to flowing water erosion of seven typical plant communities on steep gully slopes on the Loess Plateau of China. Catena, 173: 375-383.

Zhang, J., Zhao, H., Zhang, T., Zhao, X. and Drake, S. 2005. Community succession along a chronosequence of vegetation restoration on sand dunes in Horqin Sandy Land. J. Arid Environ., 62(4): 555-566.
Zhang, Q.L., Wang, Z.L., Wang, D.D. and Liu, J.E. 2017. Advances in researches on the effects of grassland vegetation on soil erosion in Loess Plateau. Adv. Earth Sci., 32(10): 1093-1101 (In Chinese).

Zhang, Y., Zhao, T.N., Shi, C.Q., Wu, H.L., Li, D.X. and Sun, Y.K. 2013. Evaluation of vegetation and soil characteristics during slope vegetation recovery procedure. Trans. Chinese Soc. Agri. Eng., 29(3): 124-131 (In Chinese).

Zhao, B.Q., Xia, Z.Y., Xun, W.N., Yang, S., Xia, D. and Wang, Z.G. 2017. Review on the research of slope eco-restoration technique for engineering disturbed area. Water Resources and Hydropower Engineering, 48(2): 130-137 (In Chinese).

Zhou, J. and Chen, G. 2012. Effect analysis of load characteristics on operation stability of hydropower stations. Energy Procedia, 17: 946-953.

Zhou, M.T., Hu, X.D. and Xu, W.N. 2016. Trend prediction of soil fertility of various substrate slopes. Bull. Soil Water Cons., 36(4): 107-111 (In Chinese).

Zhou, Z.C. and Shangguan, Z.P. 2008. Effect of ryegrasses on soil runoff and sediment control. Pedosphere, 18(1): 131-136. 